\title{
Black Grama Grass Under the Microscope; Anatomical Features of a Native Plant from Southwestern United States
}

\author{
Brigit O’Donnell*, Scott Kersey*, Lilia Gallegos*, Jerry Barrow**, and Soumitra Ghoshroy* \\ *Electron Microscopy Laboratory and Department of Biology, New Mexico State University, Las \\ Cruces, NM 88003, **USDA, Agricultural Research Service, Jornada Experimental Range, New \\ Mexico State University, Las Cruces, NM 88003
}

Black grama grass (Bouteloua eriopoda) is a perennial desert grass native to the arid Southwestern United States. It is most common in the Chihuahuan Desert, occupying large areas of New Mexico and Arizona, where occurrence of drought conditions are high. Black grama tends to grow in sandy loam soils low in organic matter [1]. However, it contains one of the highest protein contents of any desert grass, thus offering very nutritious forage for livestock and wildlife. Due to its bunchgrass-like nature, black grama aids in reducing soil erosion from rainfall. Some drought tolerance adaptive features include a root system that extends four or more feet into the soil and a small leaf blade size ( $2 \mathrm{~mm}$ wide). Unfortunately, abundance of black grama is being greatly reduced by factors such as overgrazing and invasion of Honey mesquite plants [1]. Due to the importance of black grama grass and its easily observable adaptive features, we investigated its cellular structures to find more specialized components of this plant that allow it to survive in drought conditions.

Fresh leaf blades of black grama collected in July 2002 from Jornada Experimental Range in Southwestern New Mexico were viewed and photographed with a variable pressure Hitachi S-3200N SEM. Both root and leaf samples were fixed, dehydrated, and then embedded in Spurr's epoxy resin. Thick cross sections (1-2 $\mu \mathrm{m})$ were made from these samples, stained and photographed in a Zeiss Axioplan microscope. Ultrathin sections of leaf samples were observed and photographed with a Hitachi H7000 TEM.

The leaves illustrated large bulliform cells when viewed by the SEM (fig. 1). Thick sections (figs. $2 \mathrm{~A}$ and $2 \mathrm{~B}$ ) showed the bulliform cells extending from the upper epidermis to the lower epidermis, as well as large bundle sheath cells surrounding the vascular bundles. A very thick epidermal layer (figs. 3B and 4A) and patches of thick-walled sclerenchyma cells (figs. 4A and 4B) were also visible. The stomata as observed on the surface of the leaf (fig. 3A) showed a very narrow opening and the leaf epidermis formed a curved, cap like structure over the junction of two guard cells to even further minimize water loss (fig. 3B). Radiating mesophyll cells, normally found in grass leaves (fig. 4B) were also observed under the TEM. Root structures showed presence of a very thick, highly suberized endodermal layer (fig. 5) that regulates water intake. The bulliform cells allow the plant to fold, thus minimizing water loss [2]. The thick epidermis and distribution of sclerenchyma cells also aid this function. Black grama grass has developed special structures adapted specifically to hot, dry climates. As a result, it has become an integral part of the Southwestern desert ecosystem. Because of the plant's usefulness for livestock and wildlife, it is crucial to preserve its desert habitat by regulating grazing activity as well as restricting rapidly spreading honey mesquite.

\section{References:}

[1] Drewa, P.B., et al., Proceedings of the Invasive Species Workshop. K.E.M. Galley ed. 2001.

[2] Esau, K., Anatomy of Seed Plants. $2^{\text {nd }}$ Ed., John Wiley and Sons. 1977. 

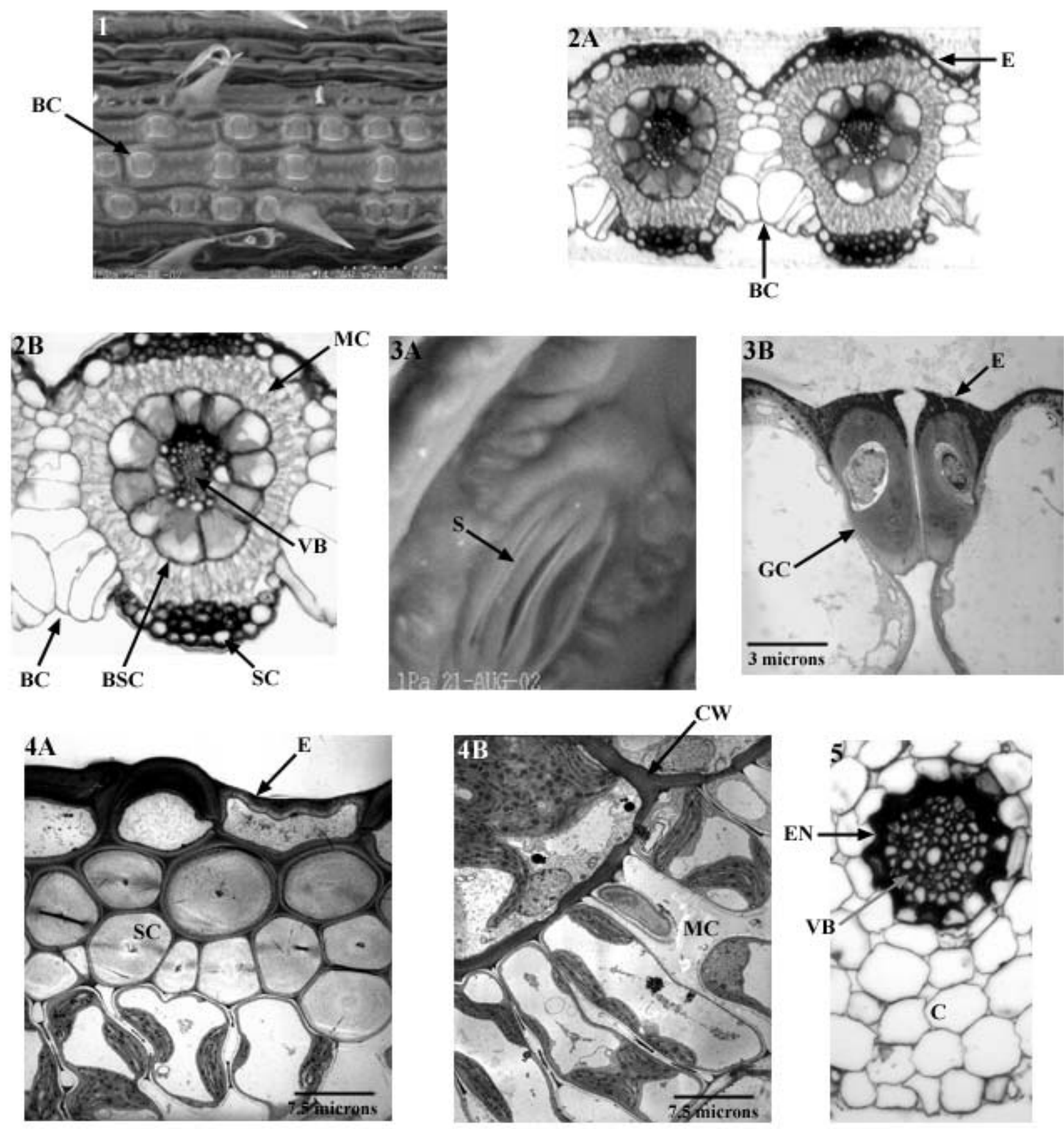

FIG. 1. Low magnification SEM image of black grama leaf surface showing rows of bulliform cells (BC).

FIG, 2A, Light microscope image of cross sectioned leaf showing leaf blade structure, epidermis (E), and bulliform cells (BC).

FIG. 2B. High magnification light microscope image of leaf blade showing sclerenchyma cells (SC), mesophyll cells (MC), bulliform cells (BC), bundle sheath cells (BSC), and vascular bundle (VB).

FIG. 3A. High magnification SEM image of leaf surface showing stomatal apparatus (S).

FIG. 3B. TEM image of stomatal guard cell (GC). Note the thick epidermis (E).

FIG, 4A. TEM image of leaf in cross section showing thick epidermis (E) and thick walled sclerenchyma (SC).

FIG, 4B. TEM image of leaf in cross section showing radiating mesophyll cells (MC), and thick cell wall (CW) of sclerenchyma cells.

FIG. 5. Low magnification image of cross sectioned black grama root showing very thick, suberized endodermis (EN), vascular tissue (VB), and cortical cells (C). 